\title{
A study on consumer's perception for green products: An empirical study from India
}

\author{
Dr Sabita Mahapatra \\ Associate Professor Marketing, \\ Indian Institute of Management, Rau, Indore, \\ India \\ sabita@iimidr.ac.in
}

\begin{abstract}
The last three decades have seen a progressive increase in worldwide environmental consciousness due to rising evidence of environmental problems. Environmental protection is increasingly becoming a necessity and part of a bigger agenda in the urbanising world of developing countries. Given the increasing deterioration of the environment, India as a developing country need to prevent pollution and preserve its natural resources. Environmental attitudes constitute a significant part of environmental consciousness. Therefore, this paper empirically investigates the attitude of Indian consumers towards the environment in general. A survey was developed and administered across India. A total of 162 Indian consumers responded completed the questionnaire. The present paper made an attempt to understand the factor that influences environment conscious behaviour for green products. The finding of the study would help government to better understand consumers' environment conscious behaviour, for developing effective environmental policies required to reinforce green purchase. Moreover, companies will have insight about how to profile green consumers in India, to develop effective messages that will functionally and emotionally appeal to their target customers.
\end{abstract}

KEYWORDS: environmental conscious attitude and behavior

ACADEMIC DISCIPLINE AND SUB-DISCIPLINES: Business Management

SUBJECT CLASSIFICATION: Consumer Behaviour

TYPE (METHOD/APPROACH): Empirical Study

\section{Council for Innovative Research}

Peer Review Research Publishing System

Journal: International Journal of Management \& Information Technology

Vol. 7, No. 1

editor@cirworld.com

www.cirworld.com, member.cirworld.com 


\section{INTRODUCTION}

The 1990s have been identified as the 'decade of the environment' (Brown and Wahlers, 1998) or as 'the Earth decade' (McDaniel and Rylander, 1993). During this decade, social and environmental concerns assumed great importance for consumer purchasing decisions (Menon et al., 1999). Firms seeking to remain competitive and to survive in the market began to incorporate these newly emerging concerns in their management and marketing decision-making (Menon et al., 1999; Straughan and Roberts, 1999; D'Souza et al., 2006; Rivera-Camino, 2007). Recently, increasing attention has been paid to the relationship between consumer behaviour, marketing and the environment.

Environmental problems are associated with human consumption; therefore the problem of conservation is highly related to consumer consumption behaviour. Hence consumers need to be responsive to reduce environmental damage through the consumption of environmental friendly products. In turn, this has an impact on marketers of consumer products (Peattie, 1992; 1995; Ottman, 1998; Paladino, 2005; Abdul-Muhmin, 2007). This will also affect policy makers and researchers who seek to influence consumers' behaviour in order to address environmental issues (Clark et al., 2003). Eco-labels are normally issued either by government supported or private enterprises only when it is proved that the product has met the criteria (Hyvärinen, 1999). Although a product may have met all the criteria for an eco-labe certification, a manufacturer would only go for such certification if consumers are wiliness to buy green product that might gives them tangible benefits. In other words, an ecolabel like any other product has to earn its acceptability and credibility in the marketplace (Knowledge Bank IIMM, 2008). D'Souza et al. (2007a) argued that environmental labels are more credible when endorsed by third party labeling experts. To enhance awareness about the environmental impacts of products, the Ministry of Environment and Forests, Government of India (Gol) had initiated a scheme in 1991, which basically was a scheme of labeling eco-friendly products (Challa, 2008). This scheme aims at distinguishing through the 'Eco-Mark', any product that is made, used or disposed of in a way that significantly reduces the adverse effect to the environment. Environmental consciousness influences decision making behaviour (Shen et al., 2005).

\section{REVIEW OF LITERATURE}

Kinnear and Taylor (1973) also stressed that the level of environmental concern demonstrated by an individual is related to his attitude and behaviour. For Maloney et al. (1975), environmental concern refers to the degree of emotionality, level of knowledge and readiness to change behaviour. Some research studies are based on the premise that people's response to environmental appeals is increasingly linked to the belief that individuals can positively influence and contribute to the solution of environmental problems (Ellen et al., 1991). Perceived consumer effectiveness was one of the variables studied by Straughan and Roberts (1999), who concluded that it was one of the variables that best explained 'ecologically conscious behaviour'. The results suggest that individuals who are concerned about the environment will only display a more proactive behaviour if they feel that their individual action may be effective in solving environmental problems (Moisander, 2007). Another factor that the literature review showed to be important and fairly influential in the relationship between environmental knowledge, attitude and behaviour is the so-called perceived behavioural control (PBC). This variable reflects the extent to which consumers believe that their participation may be effective in the preservation of the environment. Consumers with a high PBC have a more intense environmental behaviour (De Pelsmacker et al., 2002). However, there are contradictory studies that have shown the existence of a causal relationship with low levels of correlation (Antil, 1984). Environmental knowledge refers to 'how much' an individual knows about environmental issues (Chan, 1999). The variable environmental knowledge has been recognized by marketing research as a factor that influences every phase of the buying decision process. Knowledge is an important concept that affects the way in which consumers gather and organize information and determines how they evaluate products and services (Laroche et al., 2001). Nevertheless, the empirical evidence supporting the influence of environmental knowledge on behaviour is contradictory (Martin and Simintiras, 1995). On the one hand, Maloney and Ward (1973) reported that there was no significant link between environmental knowledge and favourable environmental behaviour. On the other hand, Chan (1999) showed that knowledge about environmental issues was a useful variable for predicting favourable environmental behaviour. Environmental affection refers to the degree of emotionality that an individual displays in relation to environmental issues. There seems to be consistent empirical evidence supporting the positive association between environmental affection and environmental behaviour (Maloney and Ward, 1973; Chan and Yam, 1995). These studies also show that individuals with a low level of environmental knowledge may nonetheless exhibit a close emotional relationship with the environment. In the case of the research undertaken by Chan (1999), the author noted that Chinese consumers demonstrated a powerful environmental affect, but that their actions in defense of the environment were still insignificant. Verbal commitment refers to the readiness or intention expressed by an individual to do something for the benefit of the environment (Chan, 1999). Studies have shown that there is a significant relationship between environmental intention and environmental behaviour (Maloney and Ward, 1973; Chan and Yam, 1995; Haanpää, 2007). Ecological consciousness is another factor that precedes pro environmental behaviour (Schlegelmilch and Bohlen, 1996). Such consciousness is sustained by a 'new consumer' prepared to transfer his concern with nature to his consumption decisions.

A study with 887 valid survey responses conducted on Portuguese respondents (Finisterra do Paco \& Raposo, 2008) aimed at crystallizing a set of variables into dimensions to be used in profiling green consumers. They cluster the variables into various factors which focus on a variety of green consumer aspects, such as the willingness to recycle, to carefully read labels, to conserve resources, and the willingness to pay a higher price for green products. It is surprising to note that even when environmental concern is high, the practices of environmentally responsible behaviour are not incongruence with the level of concern and knowledge (Said et al., 2003). Some studies have found in certain countries like Japan where environmental consciousness is increasing whereas environmentally friendly behaviour is not (Suzuki et al., 2004). 
Again, although no strong relationship was found between environmental knowledge and attitudes (Martin and Simintiras, 1995), environmental attitudes was found to be the most consistent predictor of pro environmental/ecological purchasing behaviour (Schlegelmilch et al., 1996; Fraj and Martinez, 2007). There are positive correlations between environmental consciousness, environmental certification involvement, perceived importance of certification and the willingness to pay for environmentally friendly products (Vlosky et al., 1999). Vlosky et al. (1999) reported environmental certification involvement and perceived importance of certification to be the strongest predictors of willingness to pay for environmentally certified products. Shoppers respond more positively to product having environmental messages while purchasing (Phau and Ong, 2007). Hyvärinen (1999) questioned whether average consumers would be willing to pay a premium for an environmentally friendly product if there is a choice of an identical and a cheaper product, which does not carry an eco-label. They also conducted detailed and objective surveys among consumers to find out whether they are indeed interested in eco matters and at what price. Das and Nath (2003) conducted a study in Delhi to examine the environmental impact of fast food industry. The study revealed that while $77 \%$ of the consumers were aware of the ingredients of the product, $62 \%$ of them didn't consider any impact the product is going to have on the environment. Less than half of the consumers (44\%) noticed the environmental benefits that fast food houses provided (e.g., use of paper bags and accessories). About $50 \%$ of the consumers were willing to take part in programs related to environment conservation while 40\% said that they are willing but didn't have time for it. McEvoy (1972), Reizenstein et al. (1974) found that males have more favorable attitude and were more inclined to pay for the control of air pollution. Contrary to this, Webster (1975), VanLiere and Dunlap (1981), Schahn and Holzer (1990), Roper Organization (1990 and 1992), Stern et al. (1993) and Scott and Willits (1994) highlighted that females have more favorable attitude towards environmental issues than their male counterparts. Whereas Kassarjian (1971), Tognacci et al. (1972), Brooker (1976), Arbuthnot (1977), Buttel and Flinn (1978), Mitchell (1983), Antil (1984), Samdhal and Robertson (1989), Straughan et al. (1999) and Sharma (2002) have concluded that there is no significant relation between gender and environmental issues. Leftridge (1978) found that place of residence was negatively correlated with perception of environmental issues. Mohai and Twight (1986) concluded that urban people are least likely to demonstrate environmental concern. Jain and Kaur (2004) undertook a study of attitudinal and behavioral analysis of Indian consumers regarding environmental issues. Survey results revealed that people believe in genuineness of sudden rise in environmental concern.

The variable age has been explored by countless green marketing researchers (see, for example, Anderson et al., 1974; Van Liere and Dunlap, 1981; Samdahl and Robertson, 1989; Jain and Kaur, 2006; D'Souza et al., 2007, etc.). On the one hand, there are studies suggesting that there is no significant correlation between age and environmental attitudes/behaviour (Kinnear et al., 1974). Others suggest that there is a significant and negative correlation (Anderson et al., 1974; Van Liere and Dunlap, 1981; Zimmer et al., 1994), while yet others have found a significant and positive correlation between age and environmental sensitivity and behaviour (Samdahl and Robertson, 1989). The development of the roles, skills and attitudes assumed by each gender has led many researchers to argue that women are more likely to present pro-environmental behaviour (Mostafa, 2007). But the results obtained in relation to this variable have not always produced similar results. For example, some studies conclude that women are more aware of and concerned with the environment than men (Berkowitz and Lutterman, 1968; Webster, 1975; Laroche et al., 2001). Mainieri and Barnett (1997) state that women tend to be more pro environmental than men, insofar as they buy more green products and participate more in the separation of packages for recycling, but they did not find any significant differences between the two genders in terms of their participation in activities for the conservation of natural resources or participation in environmentalist groups. Individuals with greater training and higher educational levels, and consequently enjoying access to more information, are expected to display greater concern, acting more frequently in favour of the environment. For example, Granzin and Olsen (1991) found that there was a positive relationship between the variable education and the variable 'walking for environmental reasons' (instead of using a car). However, this variable's explanatory capacity is not confirmed by other studies (Mainieri and Barnett, 1997). It is generally believed that income is positively correlated with environmental sensitivity. The most common justification for this situation is based on the fact that individuals with a higher income level can more easily bear the marginal increase in the costs associated with supporting 'green causes' and buying green products (Straughan and Roberts, 1999). Hooley et al. (1998) stress the importance of analyzing social class since they believe that the process of adopting new products/services and lifestyles varies according to the social class to which the individual belongs. However, this variable has been little used in studies of green marketing. The reasons for this may be related with some of the criticisms that have been made, such as the fact that this variable is likely to give rise to some confusion. Occupation, income and educational level are some of the variables that are correlated with social class, but these, in isolation, do not constitute or define such a class. Also, this type of classification ignores the individual's upward professional mobility. For Griskevicius et al. (2010), one possibility is that pro environmental behaviour might serve as a signal of personality dimensions. Do Paço and Raposo (2010) have segmented green consumers using demographic/socio-economic variables.

Additionally, predictors of environmentally conscious consumer behaviour also change over time, and ecologically conscious consumers of the1990s differ from their predecessors (Roberts, 1996). Therefore the present study aims to find out consumer's awareness for green products, factors that influences consumer's perception, consumers willing to pay for green labeled product. Uwe et al., (1993) defined perceptions as an event over time rather than as an instantaneous reaction to outside stimulation. According to Katona and Strumpel (1978), attitudes and perception are closely related. Both these concept tend to affect one's perceptions and shape one's behavior. In the international literature one can find a large body of research regarding consumers' willingness to pay for environmental friendliness and/or quality/safety in food production (Gil et al., 2000; Corsi and Novelli, 2002; Angulo et al., 2003; Baltzer, 2003; Canavari et al., 2003; Smed and Jensen, 2003), as well as for non-food products (Vlosky et al., 1999; Laroche et al., 2001) or services (Tse, 2001). Perhaps the most convincing evidence supporting the growth of ecologically favorable consumer behaviour is the increasing number of individuals who are willing to pay more for environmentally-friendly products (Laroche et al., 2001). 
However, consumers are highly fragmented in terms of their level of environmental awareness and willingness to choose higher-price environmentally oriented products (Irland, 1993). Laroche et al. (2001) argue that consumer attitudes towards the environment are very good predictors of their willing to pay for green products. On the other hand, Sriram and Forman (1993) and Teils et al. (1999) maintain that there is limited information as to how much consumers are willing to "sacrifice" for such products. Blend and van Ravenswaay (1999) assert that studies do not take into account economic factors such as prices and available income, which influence the demand for environmentally-friendly products. Govindasamy and Italia (1997) argue that, among the factors that were found to affect willing to pay, demographic characteristics such as gender, age, income and education, are among the most important. However, the same authors cite a large number of surveys show conflicting results regarding the exact demographic profile of consumers who are willing to pay. Davis et al. (1995) suggest that slight differences between gender groups are observed as regards to their willing to pay: men would pay more at a percentage of 56 percent compared to 44 percent of women.

To understand the extent to which Indian consumers may be willing to pay more for environmentally friendly products, Greenbiz.com (2005) found that as many as $71 \%$ of online consumers in India are willing to pay more for socially responsible products. Interestingly this premium that Indian consumers are willing to pay is significantly more than their counterparts in developed nations like UK where it is only $47 \%$. It is apparent that Indians believe in the genuine need to consider environmental issues and willingness for environmentally friendly steps to ameliorate environmental problems. They also report a high level of environmental concern and behaviour, and willingness to buy eco-products but feel constrained in their efforts because of a dearth of such products in the market (Jain and Kaur, 2004). Jain and Kaur (2004) have also identified high environmental concern among Indians but did not look into specific environmentally responsible behaviour. In a later study Jain and Kaur (2006) emphasized on the usefulness of demographics in predicting the environmental consciousness of Indian consumers but did not cluster green consumers or profile them. Chitra (2007) examined the awareness, knowledge, preference and attitude of Indian consumers towards eco-friendly products, cosmetics, medicines and furniture and segmented consumers into avoiders, adjusters, aspirants and addicts with majority of customers classified as aspirants. However, no previous study has analyzed the relationship between environmental awareness and various types of environmentally friendly behaviours. The result of Nik Ramli, Jusoff, \& Kassim's (2009) study in Malaysia indicated that Malaysian consumers would certainly react positively to the eco-label. Shen's (2008) study in China revealed that for Chinese consumers who believed in environmental protection and further believed that it is as an essential issue, they take into account purchasing the eco-labeled products and are also willing to pay more for those products with environmental label or eco-label. However, there appears to be no consensus in the literature about the conceptual boundaries of this concept, due, to the heterogeneous approaches that make use of it (psychology, sociology, political science, etc.) and, on the other hand, due to different contextual applications (consumption of green products, energy saving, recycling, etc.). The relevant question in this context is therefore to understand factor that influences consumer's perception and willingness to pay for green products.

\section{RESEARCH METHODOLOGY}

The study was done in central part of India. A structured questionnaire containing a battery of scales chosen from available literature was developed to assess consumer's awareness for green (certified) products and factors influencing their perception and willingness to purchase such products. A five-point Likert scale ranging from 1 (strongly agree) to 5 (strongly disagree) was used for obtaining responses. A six-point scale with anchors 1 for never to 6 for usually will be, was also employed side by side to measure respondent's frequency of engaging in environmental friendly behaviour. The draft questionnaire underwent a pretest with select consumers. Based on observations made by respondents in the pretest, modifications were made and the revised questionnaire was administered to the final set of respondents.

\section{FINDINGS}

Descriptive analysis indicated the demographic profile of the respondents, their perceptions and factors that influence their perception and willingness to pay for green products.

\section{Demographic Profile of Respondents}

As shown in Table $184 \%$ the respondents were male, while $16 \%$ were female. $53.7 \%$ of the respondents interviewed were of the age group of $21-25$ years, $38.3 \%$ in the age group of $26-35$. From the survey, $67.9 \%$ of the respondents had annual income less than 5 lacks. $34 \%$ were employed while $38.3 \%$ of the respondents' were housewife.

Table 1 Demographic profile

\begin{tabular}{|l|l|l|l|}
\hline Character & Percentage (\%) & Character & Percentage (\%) \\
\hline Gender & & Annual Income & \\
\hline Male & 84 & Less than 5 Lacs & 67.9 \\
\hline Female & 16 & $5-10$ Lacs & 21.6 \\
\hline
\end{tabular}




\begin{tabular}{|l|l|l|l|}
\hline Age & & $10-15$ Lacs & 8.0 \\
\hline Below 21 years & 0.8 & More Than 15 Lacs & 2.5 \\
\hline $21-25$ years & 53.7 & Occupation & \\
\hline 26-35 years & 38.3 & Student & 21.6 \\
\hline Above 35 years & 7.2 & Housewife & 38.3 \\
\hline & & Working & 5.6 \\
\hline & & Retired & 34.5 \\
\hline
\end{tabular}

\section{Awareness Analysis}

The frequency analysis of consumers' awareness for green products is shown in Table 2 . The results revealed that $88.3 \%$ of the respondents had heard or read about companies producing green products. $59.3 \%$ of the respondents were of the opinion that Indian companies are not sincere in promote the concept green. When respondents were asked about their understanding about the concept green, results revealed that $80 \%$ of the respondents associated green with the term as reducing pollution, recycling waste and saving energy. $60 \%$ associated it with reduction of wastage and promotion of conservation while only $25 \%$ were of the opinion that green stands for corporate social responsibility.

\section{Table 2 Consumers Awareness for Green Products}

\begin{tabular}{|c|c|}
\hline Statements & Percentage (\%) \\
\hline \multicolumn{2}{|c|}{ Are you aware of companies promoting the concept of green? } \\
\hline Yes & 88.3 \\
\hline No & 11.7 \\
\hline \multicolumn{2}{|c|}{ Do you think companies are sincere in promote green practices in India? } \\
\hline Yes & 40.7 \\
\hline No & 59.3 \\
\hline \multicolumn{2}{|c|}{ What in your opinion about the concept green? } \\
\hline Environmentally Conscious & 77.0 \\
\hline Reducing Pollution & 83.3 \\
\hline Recycling Waste & 82.7 \\
\hline Reducing Wastages & 69.8 \\
\hline Promoting Conservation & 67.9 \\
\hline Saving Energy & 85.2 \\
\hline Corporate Social Responsibility & 25.9 \\
\hline
\end{tabular}

\section{Factor influencing perception for green products}

Consumers' perceptions can influence the decision making process and buying behavior of each individual. Perceptions represent the formation of an individual state of mental awareness that is affected by internal and external environmental stimuli such as economic, social and cultural influences. Factor analysis was used to find factors influencing consumer's perception for green products. Factor analysis is interdependence technique and is used to fine the underlying structure among the variable under consideration. The interdependency technique is used to find the latent factors that account for the patterns of collinearity among multiple metric variables. The factors with factor loading $=0.50$ was considered as 
significant under each dimension. The eigen values of selected factors was greater than 1 . A total of seven factors were extracted which cumulatively account for $60.045 \%$ of the total variance in the model. Individual factor variances are indicated in table 4. The Bartlett's Test of sphericity and Kaiser-Meyer-Olkin (KMO) measure of sampling adequacy is calculated and shown in table 3. The Bartlett's test of sphericity is a test for the presence of correlation among the variables. This test provides the statistical significance that the correlation matrix has significant correlation among at least some of the variables (Hair et al., 2006). The test in this case is found to be significant with $p=0.000$. The KMO measure of sample adequacy is an index used to examine the appropriateness of factor analysis. The high value in between 0.5 to 1.0 indicates factor analysis is appropriate and value below 0.5 implies factor analysis may not be appropriate (Malhotra, 2003). The KMO value was 0.811 as shown in table 3 indicating appropriateness of the factor analysis. Table 4 summarizes the factors that influence consumers' perceptions for green products. Factor 1 represented personal benefit, factor 2 price, factor 3 convenience of use, factor 4 performance, factor 5 availability, factor 6 concern for environment and factor 7 represented health concern.

Table 3 KMO and Bartlett's Test

Kaiser-Meyer-Olkin Measure of Sampling Adequacy.

Bartlett's Test of Sphericity

Df

Sig.

.000

Table 4 Factors influencing perception for green products

\begin{tabular}{|c|c|c|}
\hline Factors & Items & Alpha \\
\hline \multirow[t]{5}{*}{$\begin{array}{l}\text { Concern for } \\
\text { Environment }\end{array}$} & $\begin{array}{l}\text { My involvement in environmental activities today will help save the } \\
\text { environment for future generations }\end{array}$ & .670 \\
\hline & $\begin{array}{l}\text { Businesses are institutions of society and therefore the problems of society } \\
\text { should also be important problems for businesses to help solve even if there is } \\
\text { no immediate monetary reward for the efforts }\end{array}$ & .719 \\
\hline & $\begin{array}{l}\text { All consumers should be interested in the environmental consequences of the } \\
\text { products they purchase }\end{array}$ & .623 \\
\hline & $\begin{array}{l}\text { I would be willing to pay a nominal increase in taxes to support greater } \\
\text { governmental control of pollution }\end{array}$ & .582 \\
\hline & I would be willing to switch brands for one that is more environmentally friendly & .516 \\
\hline \multirow[t]{4}{*}{ Safety } & Green products is safe to use & .681 \\
\hline & $\begin{array}{l}\text { The earth's resources are infinite and should be used to the fullest to increase } \\
\text { the human standard of living }\end{array}$ & .549 \\
\hline & Raw materials used in green products are of good quality & .725 \\
\hline & Green products are certified for authenticity & .786 \\
\hline \multirow{2}{*}{$\begin{array}{l}\text { Personal } \\
\text { Benefit }\end{array}$} & Green products help in saving & .729 \\
\hline & Green products help in marinating healthy life & .663 \\
\hline Health & Use of green product will increase life span & .740 \\
\hline
\end{tabular}




\begin{tabular}{|l|l|l|}
\hline \multirow{3}{*}{ Availability } & People buy green product for health concerns & $\mathbf{. 5 3 5}$ \\
\cline { 2 - 3 } & Green products are difficulty to get & $\mathbf{. 5 1 6}$ \\
\cline { 2 - 3 } & Green products are available only in few outlets & $\mathbf{. 7 3 3}$ \\
\cline { 2 - 3 } & People are not aware of availability of green products & .769 \\
\hline \multirow{2}{*}{ Price } & Green products are high priced &. $\mathbf{8 4 6}$ \\
\hline \multirow{2}{*}{ Performance } & Green product help in reducing environment pollution & $\mathbf{. 5 2 2}$ \\
\cline { 2 - 3 } & Green product are not dangerous for health &. $\mathbf{8 4 6}$ \\
\hline
\end{tabular}

\section{Willingness to pay for green products}

Table 5 shows the summary of respondents' willingness to pay for green products. $45.7 \%$ of the respondents were willing to pay around $5-10 \%$ more for green products in case they were convinced that the total ownership cost is less than actual cost. $80 \%$ of the respondents were wiliness to pay premium for green products belonging to the category like personal hygiene, food, electronics and consumer durables.

\section{Table 5 Consumers willingness to pay for green products}

\begin{tabular}{|l|l|}
\hline Willingness to pay & Percentage (\%) \\
\hline Less Than 5\% & 38.9 \\
\hline $5-10 \%$ & 45.7 \\
\hline $10-15 \%$ & 11.7 \\
\hline More than 15\% & 3.7 \\
\hline Category of Products & \\
\hline Personal Hygiene Products & 85.8 \\
\hline Food Products & 95.7 \\
\hline Clothing & 12.7 \\
\hline Kitchen Utilities & 23.9 \\
\hline Electronics & 79.6 \\
\hline Travel Related & 46.9 \\
\hline Home Products/Consumer Durables & 84.6 \\
\hline Fashion Accessories & 8.1 \\
\hline
\end{tabular}

\section{CONCLUSION}

The objective of this study was to present some insights regarding factors that influencing consumer's perceptions and willingness to pay for green products. The most significant factors found were personal benefit, price, convenience of use, performance, availability, concern for environment and health concern. These factors along with product category has significant influence in determine the total premium that an individual was willing to pay for green products. The result, thus, should be able to assist the governments, policymakers, producers and marketers in taking into consideration the market potential of the product categories for which consumer are willing to pay premium. Results of the study indicate that the majority of the respondents appeared to be aware of the concept green, though there were some differences as far as understanding of the concept green was concerned. To promote green products and practices education campaigns needs to be designed keeping in mind the message content that should reflect importance of safety, health and personal benefits. Government should strengthen its effort in informing the public about safety issues and polices related with the 
concept green by exploring mass and social media. In addition, government authorities should put their efforts in promotions consumers' awareness and positive perceptions towards green products. A certification system should be created whereby marketers would be granted certificate only if their products are guaranteed to have met the safety requirements. The local policymakers should also consider making environmental certification a mandatory requirement throughout all industry.

\section{DISCUSSION}

Differentiating a company on an environmental platform increases the perception for higher quality products and also increases consumer's willingness to purchase premium products (DeCarlo and Barone, 2005). As pressure to go green is increasing, multinational retailers like Marks and Spencer, Tesco to name a few have already started trial carbon- labeling scheme for some of its products (IGD Retail Analysis, 2008). Hence, it makes business sense for companies to adopt similar energy conservation strategies. Indeed, far-sighted companies like ITC in India have already taken steps in this direction (Singh, 2007). Other companies should follow such step to attract investors to remain competitive in the global marketplace.

An important task that any marketer would face in the coming time is to increase the consumers' knowledge about what green products is all about and to differentiate it in the market place to better target those consumers who would appreciate the positive attributes of green products. To realize the green market's true potential, business must help customers change their behaviour by removing the hurdles between intentions and actions.

\section{REFERENCE}

[1] Aini, M.S., Fakhru'l-Razi., A. Laily, P., and Jariah, M. (2003). Environmental concerns, knowledge and practices gap among Malaysian teachers. International Journal of Sustainability in Higher Education. 4(4), 305-313.

[2] Angulo, A.M., J.M. Gil and L. ( ) Renewable Agriculture and Food System, 20, 193-205.

[3] Balderjahn, Ingo. (1988). Personality Variables and Environmental Attitudes as Predictors of Ecologically Responsible Consumption Patterns. Journal of Business Research. 17(1), 51-56.

[4] Baltzer, K. (2003). Estimating Willingness to Pay for Food Quality and Safety from Actual Consumer Behaviour. paper presented at the 83rd EAAE Seminar, Chania, (September), 4-6.

[5] Bhaskaran, Polonsky, M., Cary, J. and Fernandez, S., (2006). Environmentally sustainable food production and marketing. British food Journal. 108(8), 677-690.

[6] Blend, J.R., and E.O. van Ravenswaay. (1999). Measuring Consumer Demand for Eco labeled Apples. American Journal of Agricultural Economics. 81(5), 1072-7.

[7] Bonti-Ankomah Samuel and Yiridoe K Emmanuel (2006). Organic and conventional Food: A literature Review of the economics of consumer perceptions and preferences.

[8] Canavari, M., G. Nocella., and R. Scarpa, (2003). Stated Willingness to Pay for Environment-friendly Production of Apples and Peaches: Web-based versus In-person Surveys. paper presented at the 83rd EAAE Seminar, Chania. (September), 4-6.

[9] Challa, L. (2008), Impact of textiles and clothing industry on environment: approach towards ecofriendlytextiles.http://www.fibre2fashion.com/industry-article/textile-industryarticles/impact-of-textiles-and-clothingindustry-on-environment/impact-of-textiles-and-clothing-industry-on-environment1.asp.

[10] Chitra, K. (2007). In search of the green consumers: a perceptual study. Journal of Services Research. 7, 173191.

[11] Corsi, A., and S. Novelli. (2002). Consumers' Willingness to Pay a Price for Organic Beef Meat. paper presented at the 10th EAAE Congress, Zaragoza. (August), 28-31.

[12] D'Souza, C., Taghian, M., Lamb, P. and Peretiatko, R. (2007a). Green decisions: demographics and consumer understanding of environmental labels. International Journal of Consumer Studies. 31, 204-209.

[13] Davis, A., A.J. Titterington and C. Cochrane. (1995), "Who Buys Organic Food? A Profile of the Purchasers of Organic Food in N. Ireland," British Food Journal, 97(10), 17-23.

[14] DeCarlo, T.E. and Barone, M.J. (2005), "Company environmental and societal positions as sources of competitive advantage: implications for sustainable agriculture producers," Leopold Center Progress Report, 14, 45-46.

[15] Do Paço, A. \& Raposo, M. (2010). Green consumer market segmentation: empirical findings from Portugal. International Journal of Consumer Studies. 34, 429-436.

[16] Follows, S.C. and Jobber, D. (2000), "Environmentally responsible purchase behavior - a test of a consumer model," European Journal of Marketing, 34, 723-746.

[17] Fraj, E. and Martinez, E. (2007), "Ecological consumer behavior: an empirical analysis," International Journal of Consumer Studies, 31, 26-31. 
[18] Francisco Soler (2004), "Relationship between knowledge and willingness-to-pay for organic food in Spain: evidence from experimental auctions," NJF seminar 366.

[19] Gil, J.M., A. Gracia., and M. Sanchez. (2000), "Market Segmentation and Willingness to Pay for Organic Products in Spain," International Food and Agribusiness Management Review, 3, 207-26.

[20] Govindasamy, R., and J. Italia. (1997), "Predicting the Influence of Demographic Characteristics on the Willingness to Pay for Fresh Vegetables: A Logistic Approach," Journal of Food Products Marketing, 4(4), 25-38.

[21] Greenbiz.com (2005), "Consumer survey finds doing good is good for business." http://www.sustainablemarketing.com/content/view/150/80/.

[22] Griskevicius, V., Tybur, J.M. \& Van den Bergh, B. (2010). Going green to be seen: status, reputation, and conspicuous conservation. Journal of Personality and Social Psychology. 98, 392-404.

[23] Haanpaa, L. (2007), "Consumers' green commitment: indication of a post-modern lifestyle? International Journal of Consumer Studies, 31, 478-486.

[24] Hyvärinen, A. (1999), "Eco-labeling and environmentally friendly products and production methods affecting the international trade in textiles and clothing." http://www.intracen.org/textilesandclothing/eco labelling.htm.

[25] IGD Retail Analysis (2008), “Tesco trials carbon labeling.' http://www.igd.com/analysis/news/ index. asp?nidp=\&nid=4789.

[26] Irland, L.C (1993), "Wood Producers Face Green Marketing Era: Environmentally Sound Products," Wood Technology, 120, 34.

[27] Jain, S.K. and Kaur, G. (2004), "Green marketing: an attitudinal and behavioural analysis of Indian consumers," Global Business Review, 5, 187-205.

[28] Jain, S.K. \& Kaur, G. (2006), "Role of socio-demographics in segmenting and profiling green consumers: an exploratory study of consumers in India," Journal of International Consumer Marketing, 18, 107-146.

[29] Katona, G., and B. Strumpel. (1978), "A New Economic Era.” New York: Elsevier.

[30] Knowledge Bank IIMM (2008), "Competitive labeling vs. regulatory eco-label - a look at the eco mark scheme." http://www.iimm.org/knowledge bank/8 competitive-labelingv- sregulatory-eclabel.htm

[31] Laroche M., Toffoli, R., Kim, C., and Ad Muller, T.E. (1996), "The influence of culture in pro-environment knowledge, attitude and behaviors: a Canadian perspective," Advances in Consumer Research, 23, 53-62.

[32] Laroche, M., J. Bergeron and G. Barbaro-Forleo. (2001), "Targeting Consumers who are Willing to Pay More for Environmentally Friendly Products," Journal of Consumer Marketing, 18(6), 503-20.

[33] Martin, B. and \& Simintiras, A.C. (1995), "The impact of green product lines on the environment: does what they know affect how they feel?" Marketing Intelligence and Planning, 13, 16-23.

[34] Millock, Katrin; Hansen, Lars Gårn (2002), "Willingness to Pay for Organic Foods: A Comparison between Survey Data and Panel Data from Denmark," Paper presented at Paper presented at the 12th annual EAERE (European Association of Environmental and Resource Economists) Conference, June, Monterey, USA.

[35] Nik Ramli, N. A., Jusoff, K., \& Kassim, K. M. (2009). Eco labeling perspectives among Malaysian Consumers. Canadian Social Science, 5 (2).

[36] Phau, I. and Ong, D. (2007), "An investigation of the effects of environmental claims in promotional messages for clothing brands,' Marketing Intelligence and Planning, 25, 772-788.

[37] Said, A.M., Ahmadun, F.R., Paim, L.H. and Masud, J. (2003), "Environmental concerns, knowledge and practices gap among Malaysian teachers," International Journal of Sustainability in Higher Education, 4, 305-313.

[38] Schlegelmilch, B.B., Bohlen, G.M. and Diamantopoulos, A. (1996), "The link between green purchasing decisions and measures of environmental consciousness," European Journal of Marketing, 30(5), 35-56.

[39] Shen, J. (DP-2008-E-001). Understanding the determinants of consumer's willingness to pay for eco labeled products: An empirical study on China Environmental Label. OSIPP Discussion Paper.

[40] Singh, D. (2007), "Get eco-savy or lose out on mega investments.' Times of India, 22(April), 8.

[41] Smed, S., and J.D. Jensen. (2003), "Demand for Low-Fat Dairy Products - Demand for Healthiness or Taste?," paper presented at the 83rd EAAE Seminar, Chania, (September), 4-6.

[42] Sriram, V., and A.M. Forman. (1993), "The Relative Importance of Products' Environmental Attributes: A Crosscultural Comparison," International Marketing Review, 10(3), 51-70.

[43] Suzuki, K., Futagami, T., Ogura, S., Hara, M., Ohkawa, T. and Yasui, I. (2004), Change in environmental consciousness and behavior led by information, Poster Session, 86 of the 6th International Conference on Eco Balance, Tsukuba, Japan, (October), 25-27. 
[44] Tamburo, L. (2003), "Food Safety and Consumers' Willingness to Pay for Labeled Beef in Spain," paper presented at the 83rd EAAE Seminar, Chania, (September), 4-6.

[45] Teils, M.F., B. Roe and A.S. Levy. (1999), "Eco certification: Why it May Not be a Field of Dreams," American Journal of Agricultural Economics, 81(5), 1066-71.

[46] Tse, A.C.B. (2001), "How Much More are Consumers Willing to Pay for a Higher Level of Service? A Preliminary Survey," Journal of Services Marketing, 15(1), 11-17.

[47] Vlosky, R.P., L.K. Ozanna and R.J. Fontenot. (1999), "A Conceptual Model of US Consumer Willingness-to-Pay for Environmentally Certified Wood Products," Journal of Consumer Marketing, 16(2), 122-36.

[48] Vlosky, R.P., Ozanne, L.K. and Fontenot, R.J. (1999), "A conceptual model of US consumer willingness-to-pay for environmentally certified wood products," Journal of Consumer Marketing, 16, 122-140.

[49] Yiridoe, E.K., Bonti-Ankomah, S. and Martin, R.C. (2005), "Comparison of consumer's perceptions and preferences toward organic versus conventionally produced foods": A review and update of the literature.

\section{Author' Biography}

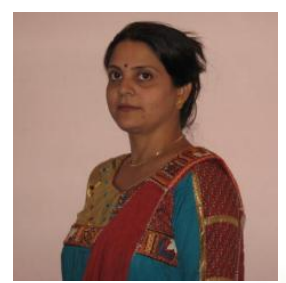

Dr. Sabita Mahapatra is Associate professor in the area of Marketing. She has more than ten years of teaching experience. She has presented several papers in National and International Conferences and credited with research publications in various referred journals. She is recipient of State \& National level Scholarship and UGC scholarships. She is member of various Institutional and professional bodies. Her area of interest includes Consumer Insight, Sales Management, Neuro/Emotional Marketing, Social Marketing, Qualitative Research, Services/Health Marketing. 